agriTECH, 40 (3) 2020, 182-189

\title{
Pengaruh Drajat Penyosohan terhadap Mutu Fisik dan Nilai Gizi Beberapa Jenis Beras
}

\author{
The Hulling Effect on Physical Quality and Nutritional Value of Different Types of Rice
}

\section{H. Hasnelly*, Evi Fitriani, Shelvi Putri Ayu, H. Hervelly}

Program Studi Teknologi Pangan, Fakultas Teknik, Universitas Pasundan, Jl. Dr. Setiabudi No. 193, Bandung 40153, Indonesia

*Penulis korespondensi: Hasnelly, E-mail: hasnelly.sriyono@gmail.com; hasnelly@unpas.ac.id

Tanggal submisi: 9 Juli 2019; Tanggal penerimaan: 4 Februari 2020

\begin{abstract}
ABSTRAK
Penyosohan pada beras tanpa mempengaruhi kualitas beras yang dihasilkan. Beras dengan perlakukan penyosohan yang tinggi mengalami penurunan nilai gizi karena beberapa nutrisi makro banyak terkandung dalam lapisan gabah yang terbuang. Tujuan dari penelitian ini untuk mengetahui pengaruh derajat penyosohan terhadap mutu dan karakteristik beberapa jenis beras: beras merah, beras hitam, dan beras putih sehingga didapatkan produk beras dengan kualitas yang baik. Regresi linier digunakan untuk mengolah data dalam penelitian ini. Pengaruh tingkat penyosohan dilihat dari beberapa respons yang diamati seperti kadar karbohidrat, kadar lemak, kadar air, kadar abu, kadar antosianin, mutu beras, rendemen beras, daya cerna pati, mutu giling, dan derajat putih beras. Hasil penelitian menunjukkan bahwa derajat penyosohan memberikan pengaruh pada sifat fisik dan kandungan nutrisi beras. Tingkat penyosohan yang rendah pada beras hitam menghasilkan kualitas beras yang baik secara fisik tinggi kandungan antosianin, dan daya cernah pati yang rendah yang baik untuk penderita diabetes.
\end{abstract}

Kata kunci: Agroindustri; beras; derajat sosoh; mutu beras

\begin{abstract}
High hulling process decreases the nutritional value and rice quality including milled rice because the macronutrient contained in the aleurone is wasted. Therefore, this study aims to ascertain the effects of hulling level on the quality and characteristics of red rice, black rice, and white rice, which would help produce high quality milled rice. Linear regression method was used, and the contents analysed were moisture, fat, ash, carbohydrate, anthocyanin, quality, rendemen, starch digestibility, and color. The results showed hulling would affect the proximate content and physical characteristics of milled rice. Also, low hulling of black rice produced the highest physical score, with high anthocyanin, and low starch digestibility which was good for diabetic consumers.
\end{abstract}

Keywords: Agroindustry; hulling level; rice; rice quality 


\section{PENDAHULUAN}

Makanan pokok sebagian besar wilayah Asia dan sebagian besar masyarakat di dunia adalah padi (Oryza sativa) sebagai sumber karbohidrat utama. International Rice Research Institute (IRRI) menyatakan bahwa Indonesia memproduksi gabah kering giling pada tahun 2017 sebanyak 37 juta ton. Masyarakat Indonesia rata-rata mengkonsumsi beras hingga $114,6 \mathrm{~kg} /$ kapita/tahun, jumlah ini melebihi konsumsi dunia pada umumnya, yaitu $60 \mathrm{~kg} / \mathrm{kapita} / \mathrm{tahun}$. Beras yang dijual di pasar rata-rata berupa beras dengan sosoh sempurna (100\%) atau beras dengan derajat sosoh $80-95 \%$.

MenurutSNI Nomor 6128-2015, mutu berasmedium I adalah dengan derajat sosoh $95 \%$ dengan beras kepala minimal sebanyak $75 \%$ dan beras patah maksimal $20 \%$ serta kadar air maksimal 14\%. Beras dengan kelas mutu medium II dan medium III memiliki kriteria yang lebih rendah dengan menurunnya syarat persentatase beras kepala dan derajat sosoh.

Penyosohan akan meningkatkan daya simpan karena proses ini akan menghilangkan aleuron tinggi lemak yang mudah teroksidasi pada padi pecah kulit (Febriandi dkk., 2017). Tingkat penyososohan 100\% akan mengakibatkan lapisan-lapisan beras rusak, salah satunya lapisan aleuron. Kandungan nutrisi beras dipengaruhi oleh proses penyosohan. Lama waktu penyosohan akan menurunkan kandungan nutrisi pada serealia karena nutrisi pada lapisan aleuron akan terbuang. Waktu penyosohan yang lama akan menurunkan kandungan fenol yang berkorelasi terhadap aktivitas antioksidan (Azis dkk., 2015)

Mutu beras dipengaruhi oleh derajat sosoh (DS). Tingginya derajat sosoh akan menurunkan mutu beras karena rendahnya beras giling yang dihasilkan dan banyaknya persentase beras patah yang dihasilkan. Mutu ini yang memberikan pengaruh pada tingkat penerimaan masyarakat dan daya beli beras. DS yang semakin tinggi dapat pula mempengaruhi kandungan gizi beras yang utama seperti daya cerna pati yang berkorelasi dengan kadar serat beras. Warna beras akan semakin cerah (putih) dengan DS yang semakin tinggi karena pigmen warna pada lapisan terluar beras merah dan beras hitam terbuang dalam jumlah banyak (Aryunis, 2012). Penyosohan secara mekanis dapat menurunkan kandungan vitamin B1, B2, B3, dan B6 pada beras merah (Indrasari, 2011).

Penelitian ini bertujuan untuk mengetahui berapa besar pengaruh derajat penyosohan serta dampaknya terhadap mutu beras dilihat dari sifat fisikokimia beberapa jenis beras, sehingga didapatkan beras dengan kandungan nutrisi yang masih tinggi dan derajat sosoh yang sesuai dengan parameter mutu.

\section{METODE PENELITIAN}

\section{Bahan}

Penelitian ini menggunakan beras putih varietas Setra Ramos, beras merah varietas Inpari 24, dan beras hitam varietas Cempo Ireng masing-masing gabah sebanyak $4 \mathrm{~kg}$. Kemudian masing-masing gabah di sosoh sesuai dengan perlakuan yang diteliti. Bahan yang digunakan untuk analisis larutan $\mathrm{H}_{2} \mathrm{SO}_{4} 6 \mathrm{~N}$, batu didih, aquadest, alkohol 95\%, larutan $\mathrm{H}_{2} \mathrm{SO}_{4} 0,3 \mathrm{~N}$, larutan $\mathrm{NaOH} 30 \%$, larutan $\mathrm{Na}_{2} \mathrm{~S}_{2} \mathrm{O}_{3} 0,1 \mathrm{~N}$, larutan $\mathrm{NaOH}$ $0,1 \mathrm{~N}$, larutan $\mathrm{HCl} 0,1 \mathrm{~N}$, larutan $\mathrm{n}$-hexan, indikator phenolphthalein.

\section{Alat}

Mesin penyosoh gabah merek Re-Rice, neraca digital, tabung reaksi, spatula, gelas kimia, pengaduk, autoclave, sendok, lumpang-alu, pembakaran bunsen, botol semprot, tang krus, tanur, kawat kassa, penangas air, pipet volumetri, pipet tetes, labu Kjeldahl, eksikator, kaca arloji, kertas timbang, labu takar $100 \mathrm{~mL}$, labu Erlenmeyer $250 \mathrm{~mL}$, destilator, kondensor, soxhlet, labu bundar, klem, statif, buret, spektrofotometer UV-Visible Serial No. A116652 merek Shimadzu Jepang, kuvet, kertas saring, dan rice grader.

\section{Penentuan Kadar Air Gabah}

Kadar air dari gabah yang akan disosoh dianalisis dengan metode gravimetri. Standar kadar air gabah menurut SNI No. 6128 tahun 2015 ialah maksimal 14\% (Sarastuti, Ahmad, \& Sutrisno, 2018).

\section{Karakterisasi Berdasarkan Tingkat Penyosohan}

Pengaruh derajat sosoh terhadap karakteristik fisik dan kandungan nutrisi beras hasil sosoh diamati berdasarkan beberapa respons yang ditentukan: rendemen (perbandingan berat), derajat putih (perbandingan warna sebelum dan setelah penyosohan), mutu giling (persentase beras kepala, beras patah, dan butir menir), kadar air (gravimetri), kadar abu (gravimetri), kadar karbohidrat (metode by difference), kadar lemak (metode Soxhlet), kadar protein (metode Kjedahl), kadar antosianin (metode spektrofotometri), daya cerna pati, dan kadar serat kasar. Metode penelitian menggunakan regresi linier sederhana dengan rumus $Y$ $=\mathrm{a}+\mathrm{bX}$. Variabel bebas $(\mathrm{x})$ tingkat penyosohan ialah x1 (1 kali), x2 (2 kali), x3 (3 kali), dan variabel terikat (y) ialah masing-masing respons yang akan dianalisis. Nilai koefisien korelasi atau $r$ dihitung berdasarkan Persamaan 1. 


$$
r=\frac{n \sum x i y i-\left(\sum x i\right)\left(\sum y i\right)}{\sqrt{\left\{n \sum_{x i} 2-\left(\sum x i\right) 2\right\}\left\{n \sum_{y i} 2-\left(\sum y i\right) 2\right\}}}
$$

\section{HASIL DAN PEMBAHASAN}

\section{Kadar Air Gabah}

Kadar air gabah pada ketiga varietas tidak berbeda jauh karena sebelum disimpan gabah dilakukan pengeringan. Gabah beras putih (Setra Ramos) memiliki kadar air sebesar $11,46 \%$, gabah beras merah (Inpari 24) memiliki kadar air sebesar $11,05 \%$, dan gabah beras hitam (Cempo Ireng) mengandung kadar air sebesar $11,44 \%$. Kadar air gabah telah memenuhi standar kadar air yang aman untuk penyimpanan gabah. Mutu dan daya simpan gabah dipengaruhi oleh kadar air gabah. Kadar air dapat mempengaruhi mutu beras giling yang dihasilkan. Kerusakan gabah secara kimia, biokimia, dan mikrobiologi dipicu oleh kadar air yang tinggi (Aryunis, 2012).

\section{Karakteristik Gabah Berdasarkan Tingkat Penyosohan}

Karakteristik fisikokimia gabah yang dianalisis meliputi analisis rendemen, mutu giling, derajat putih, kadar air, kadar abu, kadar lemak, kadar protein, kadar karbohidrat, daya cerna pati, kadar serat kasar, juga kadar antosianin pada beras merah dan beras hitam.

\section{Rendemen Beras}

Rendemen beras sosoh ialah nisbah berat beras sosoh yang dihasilkan dengan berat awal gabah. Hasil analisis pengukuran rendemen berbagai jenis beras yang disosoh dengan tingkat penyosohan yang berbeda (Tabel 1) menunjukkan bahwa tingkat penyosohan akan mempengaruhi rendemen beras sosoh. Rendemen setiap jenis beras akan berkurang dengan semakin tingginya tingkat penyosohan yang diberikan. Semakin tinggi tingkat penyosohan maka rendemen akan semakin menurun karena banyaknya lapisan bekatul yang hilang selama proses penyosohan.

Tabel 1. Hasil analisis rendemen gabah

\begin{tabular}{llll}
\hline \multirow{2}{*}{$\begin{array}{l}\text { Tingkat } \\
\text { Penyosohan }\end{array}$} & \multicolumn{3}{c}{ Rendemen* } \\
\cline { 2 - 4 } & Beras putih & Beras merah & Beras hitam \\
\hline 1 kali & 68,80 & 67,20 & 65,00 \\
2 kali & 65,40 & 62,80 & 60,00 \\
3 kali & 62,80 & 58,80 & 54,80 \\
Nilai r & 0,9970 & 0,9996 & 0,9999 \\
\hline
\end{tabular}

Keterangan: *dalam \%

\section{Mutu giling}

Derajat penyosohan akan menurunkan persentase beras kepala namun menaikkan persentase beras patah dan butir menir pada ketiga jenis beras (Tabel 2). Persentase beras kepala, beras patah dan butir menir menjadi parameter penting dalam menentukan mutu beras (Hassan, 2014). Beras yang mengandung banyak butir patah disebut beras mutu rendah karena harga beras di tingkat penggilingan akan murah (Bella dkk., 2013). Semakin tinggi tingkat penyosohan maka persentase beras kepala akan berkurang, namun persentase beras patah akan meningkat pada semua jenis beras. Derajat sosoh yang semakin tinggi akan kontak langsung pada bagian endosperm, sehingga persentase beras patah semakin tinggi oleh rusaknya sel-sel pati dalam beras akibat dari rendahnya kadar air karena peningkatan suhu saat penyosohan (Sarastuti dkk., 2018). Tingkat penyosohan mempengaruhi mutu giling beras. Beras putih dengan tingkat penyosohan yang rendah menghasilkan persentase beras kepala yang tinggi, begitu pula pada beras merah dan beras hitam.

Tabel 2. Hasil analisis mutu giling

\begin{tabular}{|c|c|c|c|}
\hline $\begin{array}{c}\text { Tingkat } \\
\text { penyosohan }\end{array}$ & Beras putih & Beras merah & Beras hitam \\
\hline & Beras kepala* & & \\
\hline 1 kali & 74,52 & 82,69 & 71,83 \\
\hline 2 kali & 73,09 & 81,49 & 69,48 \\
\hline \multirow[t]{2}{*}{3 kali } & 72,27 & 80,59 & 68,77 \\
\hline & Beras patah* & & \\
\hline 1 kali & 25,38 & 17,12 & 27,99 \\
\hline 2 kali & 26,80 & 18,14 & 30,30 \\
\hline \multirow[t]{2}{*}{3 kali } & 27,58 & 19,04 & 30,98 \\
\hline & Butir menir* & & \\
\hline 1 kali & 0,10 & 0,19 & 0,18 \\
\hline 2 kali & 0,11 & 0,37 & 0,22 \\
\hline 3 kali & 0,15 & 0,37 & 0,25 \\
\hline
\end{tabular}

Keterangan: *dalam \%

\section{Derajat putih}

Pengukuran terhadap perubahan warna pada beras merah dan beras hitam bertujuan untuk mengenali tingkat penurunan kualitas warna akibat dari proses penyosohan. Derajat putih beras mengalami peningkatan dengan semakin tingginya tingkat penyosohan (Gambar 1). Perbedaan warna dari beras yang dihasilkan dipengaruhi oleh jumlah pigmen warna pada beras (antosianin). Beras akan semakin putih jika 

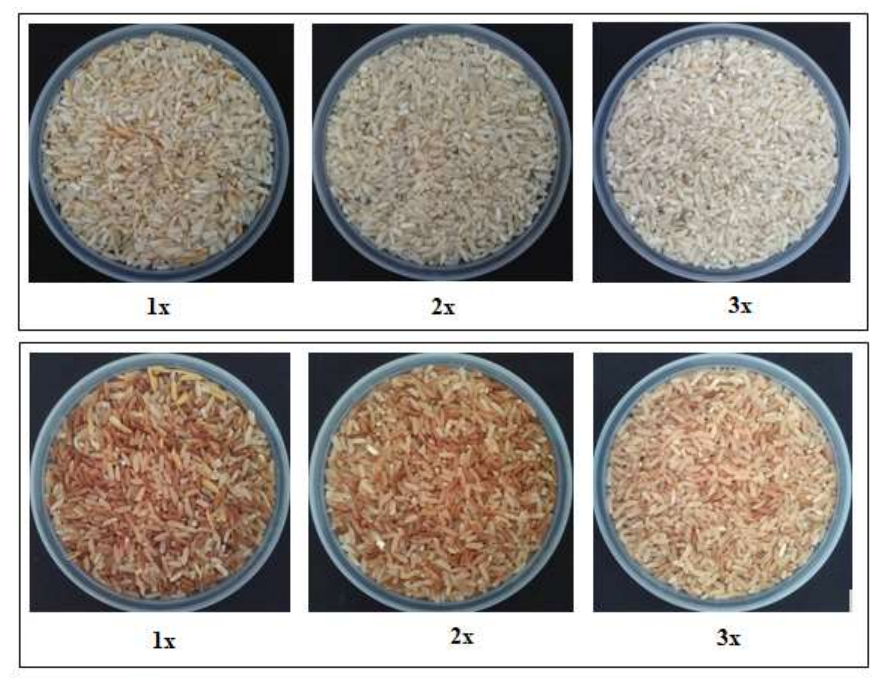

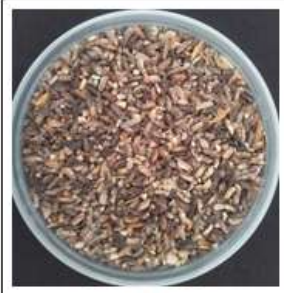

$1 \mathrm{x}$

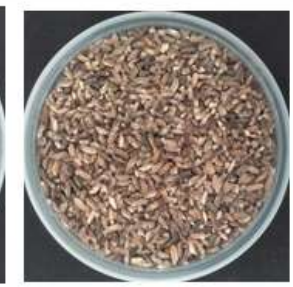

$2 \mathrm{x}$

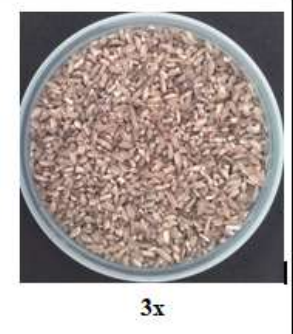

$3 \mathbf{x}$
Gambar 1. Beras dengan berbagai tingkat penyosohan

pigmen warnanya menurun. Warna kuning dan merah terkonsentrasi pada endosperm luar beras. Antosianin terkandung dalam beras sebagai zat pemberi warna merah (Febriandi dkk., 2017). Tingkat kandungan antosianin tertinggi terdapat pada beras hitam, lalu beras merah, sedangkan pada beras putih hampir tidak ada (Widyawati dkk., 2014). Hilangnya pigmen antosianin beras yang terdapat pada lapisan aleuron atau bekatul yang melekat pada endosperm mengakibatkan warna beras sosoh menjadi lebih putih. Tingkat penyosohan mempengaruhi derajat putih beras yang dihasilkan. Beras dengan tingkat penyosohan yang rendah akan mengandung tinggi antosianin yang bermanfaat sebagai antioksidan.

\section{Kadar air}

Parameter kadar air maksimum beras umumnya sebesar $14 \%$ sebagaimana yang disyaratkan oleh SNI No.6218 tahun 2015. Penyosohan akan meningkatkan kadar air pada ketiga jenis beras (Tabel 3). Derajat penyosohan yang berbeda akan menghasilkan perbedaan tingkat absorpsi air pada ketiga jenis beras. Kemampuan beras pecah kulit lebih tinggi dalam menyerap air jika dibandingkan dengan beras giling. Kandungan amilosa pada beras pecah kulit menjadi faktor penentunya karena daya serap air dipengaruhi
Tabel 3. Hasil analisis kadar air

\begin{tabular}{clcc}
\hline \multirow{2}{*}{$\begin{array}{c}\text { Tingkat } \\
\text { penyosohan }\end{array}$} & \multicolumn{3}{l}{ Kadar air* } \\
\cline { 2 - 4 } & Beras putih & Beras merah & Beras hitam \\
\hline 1 kali & 10,07 & 9,93 & 9,76 \\
2 kali & 10,34 & 10,20 & 10,42 \\
3 kali & 10,36 & 10,43 & 10,69 \\
Nilai $r$ & 0,8952 & 0,9989 & 0,9719 \\
\hline
\end{tabular}

Keterangan: *dalam \%

oleh kadar amilosa dan suhu penyimpanan beras (Basito, 2010). Tingkat penyosohan akan mempengaruhi kadar air beras. Beras dengan tingkat penyosohan yang rendah akan mengandung kadar air yang rendah yang dapat bermanfaat pada umur simpan beras.

\section{Kadar abu}

Abu/mineral banyak terdapat pada lapisan bran dari gabah. Penyosohan menurunkan kadar abu pada ketiga jenis beras (Tabel 4). Kadar abu dihitung dengan memanaskan dan membakar sampel pada suhu yang sangat tinggi $\left(600-700{ }^{\circ} \mathrm{C}\right)$. Kadar abu umumnya bersifat linier dengan kandungan mineral beras. Kadar abu diukur sebagai kandungan mineral dalam beras (Umar dkk, 2013). Mineral dan besi terkandung dalam lapisan aleurone dalam beras yang menentukan kadar abu beras. Lapisan aleurone akan berkurang selama proses penyosohan (Nugraha, Tamrin, dan Asyik, 2018). Tingkat penyosohan akan mempengaruhi kadar abu dalam beras. Tingkat penyosohan yang tinggi dapat memberikan kandungan mineral yang rendah.

Tabel 4. Hasil analisis kadar abu

\begin{tabular}{cccc}
\hline Tingkat & \multicolumn{3}{c}{ Kadar abu* } \\
\cline { 2 - 4 } penyosohan & Beras putih & Beras merah & Beras hitam \\
\hline 1 kali & 0,94 & 0,93 & 1,12 \\
2 kali & 0,90 & 0,56 & 0,88 \\
3 kali & 0,58 & 0,52 & 0,76 \\
Nilai r & 0,9122 & 0,9069 & 0,9819 \\
\hline
\end{tabular}

Keterangan: *dalam \%

\section{Kadar lemak}

Lemak terkandung dalam lapisan bekatul beras dan menjadi salah satu parameter penting untuk mengukur derajat sosoh. Kadar lemak pada ketiga jenis beras mengalami penurunan setelah penyosohan (Tabel 5) dimana hasil yang sama ditunjukkan oleh hasil penelitian yang Elsera (2011) lakukan, yang menunjukkan bahwa derajat penyosohan akan menurunkan kadar lemak 
Tabel 5. Hasil analisis kadar lemak

\begin{tabular}{cccc}
\hline \multirow{2}{*}{$\begin{array}{c}\text { Tingkat } \\
\text { penyosohan }\end{array}$} & \multicolumn{3}{c}{ Kadar lemak* } \\
\cline { 2 - 4 } & Beras putih & Beras merah & Beras hitam \\
\hline 1 kali & 2,80 & 3,80 & 2,50 \\
2 kali & 1,60 & 1,70 & 1,80 \\
3 kali & 1,30 & 1,40 & 1,40 \\
Nilai $r$ & 0,9449 & 0,9177 & 0,9878 \\
\hline
\end{tabular}

Keterangan: *dalam \%

(Tarigan \& Kusbiantoro, 2011). Asam linoleat, asam oleat, dan asam palmitat merupakan asam lemak yang terkandung pada beras pecah kulit (Juliano, 1972). Beras giling mengandung lebih sedikit asam-asam lemak tersebut karena sebagian komponen beras hilang saat penggilingan dan penyosohan. Kadar lemak pada beras pecah kulit lebih tinggi dibandingkan pada beras hasil penyosohan (Tarigan \& Kusbiantoro, 2011). Umur tanaman dapat mempengaruhi kandungan lemak beras. Usia pemanenan yang lebih dari umur optimum dapat meningkatkan kandungan lemak (Nugraha dkk., 2018). Lemak terakumulasi pada lapisan pericarp dan aleurone (Febriandi dkk., 2017). Aleuron yang tinggi kandungan lemak akan hilang pada proses penyososohan. Padi pecah kulit akan menyebabkan kandungan lemak rentan terhadap oksidasi, sehingga daya simpan dapat ditingkatkan dengan proses penyosohan (Febriandi dkk, 2017). Bahan pangan kategori rendah lemak mengandung lemak dengan kadar maksimal 3\% (Azis dkk., 2015). Tingkatpenyosohan dapatberpengaruh pada kadar lemak beras yang dapat memperpanjang umur simpan beras, hal ini didukung oleh pernyataan Elsera (2011) pada artikelnya yang menyatakan bahwa beras dapat mengalami ketengikan karena terjadinya proses oksidasi asam lemak, selain itu selama penyimpanan kadar lemak akan mengalami peningkatan, sehingga jika kadar lemak awal sudah tinggi maka penurunan kualitas beras akan cepat (Tarigan \& Kusbiantoro, 2011), oleh sebab itu kandungan asam lemak yang rendah dapat menghambat proses penurunan kualitas tersebut.

\section{Kadar protein}

Protein merupakan penyusun beras terbesar selanjutnya setelah pati, mempunyai ukuran granula 0.5-5 m, serta terdiri dari $5 \%$ fraksi albumin, $10 \%$ globulin, $5 \%$ prolamin, dan $80 \%$ glutelin (Juliano, 1972). Kadar protein pada ketiga jenis beras mengalami penurunan setelah penyosohan (Tabel 6). Protein pada beras banyak terdapat pada lembaga, pericarp, dan endosperm (Febriandi dkk., 2017). Penyosohan meyebabkan hilangnya bekatul beras yang mengandung
Tabel 6. Hasil analisis kadar protein

\begin{tabular}{cccc}
\hline \multirow{2}{*}{$\begin{array}{c}\text { Tingkat } \\
\text { penyosohan }\end{array}$} & \multicolumn{3}{c}{ Kadar protein* } \\
\cline { 2 - 4 } & Beras putih & Beras merah & Beras hitam \\
\hline 1 kali & 9,69 & 6,98 & 10,00 \\
2 kali & 7,61 & 4,52 & 9,48 \\
3 kali & 4,48 & 4,08 & 7,17 \\
Nilai r & 0,9933 & 0,9277 & 0,9393 \\
\hline
\end{tabular}

Keterangan: *dalam \%

protein sehingga kadar protein beras akan menurun. Penggilingan beras dengan derajat sosoh yang tinggi menyebabkan hilangnya asam amino esensial seperti asam glutamat, lisina dan asam tartarat. Tingkat penyosohan berpengaruh pada kadar protein beras. Tingkat penyosohan yang rendah baik digunakan untuk mendapatkan beras dengan kandungan protein yang tinggi.

\section{Kadar karbohidrat}

Karbohidrat dalam beras sebagian besar terkandung sebagai fraksi pati. Kadar karbohidrat ditentukan menggunakan metode by difference. Kadar karbohidrat pada beras putih, beras merah, dan beras hitam mengalami peningkatan (Tabel 7). Karbohidrat yang terdapat dalam beras terkonsentrasi pada bagian endosperm. Semakin tinggi tingkat penyosohan menyebabkan peningkatan kadar karbohidrat karena berkurangnya lapisan bran (bekatul) beras.

Lapisan bekatul akan berkurang setelah penyosohan tetapi tidak mempengaruhi kandungan karbohidrat secara jauh karena karbohidrat beras juga terkandung pada endosperm sebagai bagian terbesar dari butiran beras. Penyosohan akan meningkatkan kadar karbohidrat dibandingkan dengan beras pecah kulit. Derajat penyosohan akan meningkatkan kandungan pati dan amilosa (Febriandi dkk., 2017). Kadar karbohidrat beras umumnya ialah 78\% (Hernawan \& Meylani, 2016). Tingkat penyosohan mempengaruhi kadar karbohidrat pada beras. Tingkat penyosohan yang tinggi merupakan

Tabel 7. Hasil analisis kadar karbohidrat

\begin{tabular}{cccc}
\hline \multirow{2}{*}{$\begin{array}{c}\text { Tingkat } \\
\text { penyosohan }\end{array}$} & \multicolumn{3}{c}{ Kadar karbohidrat* } \\
\cline { 2 - 4 } & Beras putih & Beras merah & Beras hitam \\
\hline 1 kali & 75,71 & 77,84 & 75,68 \\
2 kali & 79,55 & 83,82 & 77,42 \\
3 kali & 83,57 & 84,07 & 80,67 \\
Nilai $r$ & 0,9998 & 0,8832 & 0,9851 \\
\hline
\end{tabular}

Keterangan: *dalam \% 
proses terbaik untuk menghasilkan produk beras dengan kandungan karbohidrat yang tinggi.

\section{Kadar serat kasar}

Serat kasar (crude fiber) merupakan bagian bahan pangan yang sudah tidak terhidrolisis kembali oleh senyawa kimia berupa asam kuat dan basa kuat. Kadar serat pada ketiga jenis beras mengalami penurunan selama penyosohan (Tabel 8). Tingkat penyosohan yang tinggi akan menurunkan kadar serat kasar pada beras. Komponen serat yang tidak larut pada beras meliputi selulosa dan hemiselulosa yang berada pada lapisan aleuron berpotensi mengalami kehilangan akibat perlakuan penyosohan. Serat kasar akan semakin banyak terbuang seiring dengan tingginya tingkat penyosohan yang berupa bekatul atau sekam. Kandungan serat dipengaruhi oleh penyerapan unsur nitrogen dari tanah, umur simpan tanaman, dan lama penyimpanan setelah panen (Nugraha dkk., 2018). Penyosohan yang berbeda memberikan pengaruh terhadap kadar serat kasar beras yang dihasilkan. Tingkat penyosohan tinggi merupakan proses terbaik untuk mendapatkan produk dengan kadar serat yang rendah.

Tabel 8. Hasil analisis kadar serat kasar

\begin{tabular}{cccc}
\hline Tingkat & \multicolumn{3}{c}{ Kadar serat* } \\
\cline { 2 - 4 } penyosohan & Beras putih & Beras merah & Beras hitam \\
\hline 1 kali & 3,48 & 3,49 & 3,00 \\
2 kali & 2,49 & 3,47 & 2,98 \\
3 kali & 2,00 & 2,99 & 2,48 \\
Nilai $r$ & 0,9815 & 0,8832 & 0,8825 \\
\hline
\end{tabular}

Keterangan: *dalam \%

\section{Kadar antosianin}

Antosianin merupakan bagian dari flvonoid yang berperan sebagai pigmen dan bersifat antioksidatif. Senyawa antosianin beras terkandung dalam bentuk sianidin-3-glukosida, peonidin-3-glukosida, dan turunannya. Total antosianin diuji dan dinyatakan dalam satuan ekuivalen sianidin-3-glukosida karena 93\% antosianin pada beras merah dan beras hitam terkandung dalam bentuk sianidin-3-glukosida. Beras hitam mengandung antosianin dan senyawa fenolik yang lebih tinggi (Widyawati dkk., 2014). Perlakuan penyosohan yang tinggi mengakibatkan warna beras merah yang semula merah menjadi semakin putih karena kandungan antosianin yang berkurang (Tabel 9 ). Kandungan antosianin didalam beras merah dan beras hitam banyak yang hilang atau terbuang dalam bentuk bekatul. Pada derajat penyosohan $80 \%$ kadar antosianin
Tabel 9. Hasil analisis kadar antosianin

\begin{tabular}{ccc}
\hline \multirow{2}{*}{ Tingkat penyosohan } & \multicolumn{2}{c}{ Kadar antosianin } \\
\cline { 2 - 3 } & Beras merah & Beras hitam \\
\hline 1 kali & 7,390 & 51,495 \\
2 kali & 4,440 & 49,315 \\
3 kali & 3,935 & 42,175 \\
Nilai $r$ & 0,9257 & 0,9559 \\
\hline
\end{tabular}

Keterangan: *dalam ppm

pada beras merah akan turun sekitar $17 \%$, sedangkan pada derajat penyosohan $100 \%$ akan menurunkan kadar antosianin beras merah sebesar 25\% (Febriandi dkk., 2017). Proses penggilingan dan penyimpanan menjadi faktor yang mempengaruhi kulit ari beras terkelupas. Beras merah dan beras hitam digiling dengan cara yang berbeda dari beras putih agar kulit ari beras tidak hilang (Nugraha dkk., 2018). Derajat penyosohan memberikan pengaruh pada kadar antosianin beras hitam dan beras merah. Tingkat penyosohan yang rendah merupakan proses terbaik untuk menghasilkan produk dengan kandungan antosianin yang tinggi.

\section{Daya cerna pati}

Daya cerna pati merupakan kemampuan enzim a-amilase untuk menghidrolisis pati menjadi bentuk yang lebih sederhana, sehingga mudah untuk diserap oleh tubuh (Hidayati dkk., 2016). Semakin tinggi tingkat penyosohan maka daya cerna pati semakin meningkat (Tabel 10). Derajat sosoh menyebabkan granula-granula pati yang berfungsi sebagai pelindung endosperm menjadi rusak, akibatnya struktur pati dalam endosperm menjadi semakin halus dan beberapa komponen pelindungnya terbuang akibat penyosohan sehingga pati akan semakin mudah dicerna (Kurniawan, 2014). Kandungan serat kasar menjadi faktor lain yang dapat mempengaruhi daya cerna pati beras. Tingginya kandungan serat akan membuat daya cerna pati yang rendah. Serat tersebut dapat meningkatkan viskositas

Tabel 10. Hasil analisis daya cerna pati

\begin{tabular}{cccc}
\hline \multirow{2}{*}{$\begin{array}{c}\text { Tingkat } \\
\text { penyosohan }\end{array}$} & \multicolumn{3}{c}{ Daya cerna pati* } \\
\cline { 2 - 4 } & Beras putih & Beras merah & Beras hitam \\
\hline 1 kali & 75,6578 & 61,3873 & 64,3251 \\
2 kali & 76,3528 & 63,5435 & 64,4573 \\
3 kali & 79,7112 & 66,3555 & 68,9263 \\
Nilai r & 0,9349 & 0,9971 & 0,8783 \\
\hline
\end{tabular}

Keterangan: *dalam \% 
pangan di dalam usus, sehingga dapat menghambat interaksi enzim terhadap pati. Daya cerna pati yang tinggi akan mempercepat penguraian karbohidrat menjadi glukosa yang mempengaruhi respons glikemik pada proses metabolisme (Nurhidajah dkk., 2015). Derajat penyosohan mempengaruhi daya cerna pati beras. Tingkat penyosohan yang tinggi ialah proses terbaik untuk mendapatkan produk dengan daya cerna pati yang tinggi.

\section{KESIMPULAN}

Berdasarkan hasil penelitian, dapat disimpulkan derajat penyosohan sangat mempengaruhi karakteristik fisik dan kandungan nutrisi beras putih, beras merah, dan beras hitam. Tingginya tingkat penyosohan akan menurunkan jumlah rendemen, mutu giling, kadar air, kadar protein, kadar abu, kadar serat, dan kadar lemak beras. Namun, kadar karbohidrat, derajat putih, dan daya cerna pati mengalami peningkatan setelah penyosohan. Data hasil penelitian menunjukkan bahwa dari ketiga jenis beras yang dianalisis, beras hitam dengan tingkat penyosohan 1 kali memiliki kandungan nutrisi dan kadar antosianin yang lebih tinggi dibandingkan yang lainnya serta memiliki daya cerna pati rendah. Karakteristik beras seperti ini sangat baik untuk dikonsumsi oleh penderita diabetes.

\section{UCAPAN TERIMA KASIH}

Terima kasih kepada Kementrian Negara Riset dan Teknologi yang telah membiayai penelitian dan publiksi jurnal ini melalui Program Riset Unggulan Perguruan Tinggi Tahun 2018-2019 dan Fakultas Teknik Universitas Pasundan Bandung.

\section{KONFLIK KEPENTINGAN}

Bagian ini menyatakan mengenai konflik kepentingan yaitu kami tidak mempunyai hubungan dengan tim editor agriTECH. Kami tidak mempunyai hubungan dengan tim editor agriTECH sampai 2 (dua) tingkat garis keluarga. Kami tidak akan menawarkan memberikan hadiah dan atau menerima pemberian dalam bentuk dan atau cara apapun kepada setiap tim jurnal agriTECH terkait dalam proses publikasi atas manuskrip yang telah dikirimkan. Manuskrip yang kami kirimkan adalah orisinil dan belum pernah dipublikasi di jurnal manapun. Kami menyatakan bahwa informasi di atas adalah benar dan atas setiap penyimpangan atau ketidakbenaran dari pernyataan tersebut di atas maka kami akan menerima segala keputusan Jurnal agriTECH termasuk tetapi tidak terbatas pada penolakan dari agriTECH kepada kami dalam setiap kesempatan publikasi jurnal.

\section{DAFTAR PUSTAKA}

Aryunis. (2012). Evaluasi Mutu Gabah Padi Lokal Pasang Surut Asal Kecamatan Tungkal Ilir Kabupaten Tanjung Jabung Barat. Jurnal Penelitian Universitas Jambi Seri Sains, 14(2), 47-50.

Azis, A., Izzati, M., \& Haryanti, S. (2015). Aktivitas Antioksidan Dan Nilai Gizi Dari Beberapa Jenis Beras Dan Millet Sebagai Bahan Pangan Fungsional Indonesia. Jurnal Biologi, 4(1), 45-61.

Basito. (2010). Kajian Karakteristik Fisikokimia dan Sensori Beras Organik Mentik Susu dan IR64; Pecah Kulit dan Giling Selama Penyimpanan. Jurnal Teknologi Hasil Pertanian, 3(2), 95-101. https://doi.org/10.20961/jthp. v0i0.13636

Bella, A. A., Marwanti, S., \& Ani, S. W. (2013). Evaluasi Mutu Beras Di Tingkat Penggilingan Padi Skala Kecil Di Kecamatan Plupuh Kabupaten Sragen. Prosiding Seminar Nasional Fakultas Pertanian UNS, 552-557.

Febriandi, E., Sjarief, R., \& Widowati, S. (2017). Studi Sifat Fisikokimia dan Fungsional Padi Lokal (Mayang Pandan) Pada Berbagai Derajat Sosoh. Jurnal Penelitian Pascapanen Pertanian, 14(2), 79-87. http://dx.doi. org/10.21082/jpasca.v14n2.2017.79-87

Hassan, Z. H. (2014). Kajian Rendemen dan Mutu Giling Beras di Kabupaten Kotabaru Provinsi Kalimantan Selatan. Jurnal Pangan, 23(3), 232-242. http://dx.doi.org/ 10.33964/jp.v23i3.67

Hernawan, E., \& Meylani, V. (2016). Analisis Karakteristik Fisikokimia Beras Putih, Beras Merah, dan Beras Hitam. Jurnal Kesehatan Bakti Tunas Husada, 15(1), 79-91. http://dx.doi.org/10.36465/jkbth.v15i1.154

Hidayati, S., Nurdin, S. U., \& Nugroho, R. A. (2016). Aktivitas Antioksidan dan Sifat Sensori Nasi Instan Hasil Hidrolisis Pati yang Diperkaya dengan Ekstrak Pegagan. Jurnal Teknologi Industri Dan Hasil Pertanian, 21(2), 77-88. http://dx.doi.org/10.23960/jtihp.v21i2.77\%20-\%2088

Indrasari, S. D. (2011). Pengaruh Penyosohan Gabah dan Pemasakan terhadap Kandungan Vitamin B Beras Merah. Jurnal Penelitian Pertanian Tanaman Pangan, 30(3), 182-188. http://dx.doi.org/10.21082/jpptp. v30n3.2011.p\%25p

Nugraha, M. I., Tamrin, \& Asyik, N. (2018). Karakterisasi Sifat Fisik, Kimia, dan Aktivitas Antioksidan Pada Beras Merah Varietas Bulo Bulo Asal Kabupaten Kolaka Dan Kabupaten Konawe Selatan. Jurnal Sains Dan Teknologi Pangan, 3(3), 1283-1296.

Nurhidajah, Astuti, M., Sardjono, Murdiati, A., \& Marsono, Y. (2015). Kadar Serat Pangan dan Daya Cerna Pati Nasi 
Merah yang Diperkaya Kappa-karagenan dan Ekstrak Antosianin dengan Variasi Metode Pengolahan. The 2nd University Research Coloquium.

Sarastuti, S., Ahmad, U., \& Sutrisno, S. (2018). Analisis Mutu Beras dan Penerapan Sistem Jaminan Mutu Dalam Kegiatan Pengembangan Usaha Pangan Masyarakat. Jurnal Penelitian Pascapanen Pertanian, 15(2), 12-21. http://dx.doi.org/10.21082/jpasca.v15n2.2018.63-72

Tarigan, E., \& Kusbiantoro, B. (2011). Pengaruh Derajat Sosoh Dan Pengemas Terhadap Mutu Beras Aromatik Selama Penyimpanan. Jurnal Penelitian Pertanian Tanaman Pangan, 30(1), 30-37. https://doi.org/10.21082/jpptp. v30n1.2011.p
Umar, M. A., Ugonor, R., Akin-Osanaiye, C. B., \& Kolawole, S. A. (2013). Evaluation Of Nutritional Value Of Wild Rice From Kaduna State, Central Nigeria. International Journal of Scientific \& Technology Research, 2(7), 140147.

Widyawati, P. S., Suteja, A. M., Indarto, T., Suseno, P., Monika, P., Saputrajaya, W., \& Liguori, C. (2014). Effect of Pigment Color Difference in Organic Rice on Antioxidant Activity. Agritech, 34(4), 399-406. https://doi.org/10.22146/ agritech.9434 